\title{
Effect of Propaquizafop on Weed Count, Yield Attributes and Yield of Soybean under Mid Hill Conditions of Himachal Pradesh, India
}

\author{
Sachin Kumar*, M.C. Rana and S.S. Rana \\ Department of Agronomy, Forages and Grassland Management, CSK HPKV, \\ Palampur-176062, India \\ *Corresponding author
}

A B S T R A C T

\section{Keywords}

Propaquizafop, Soybean, Weed count, Yield, Yield attributes

\section{Article Info}

Accepted:

07 March 2018

Available Online:

10 April 2018
Field experiment was conducted to find out the effectiveness of eleven weed control treatments including weedy check in soybean. Propaquizafop $50 \mathrm{~g}+$ imazethapyr $100 \mathrm{~g} / \mathrm{ha}$ on 20 DAS was as effective as hand weeding twice in reducing the population of $E$. colona, Commelina banghalensis, Cyperus iria, Ageratum conyzoides and Polygonum alatum. Propaquizafop alone was not effective against A. conyzoides and $P$. alatum. Application of propaquizafop $75 \mathrm{~g} / \mathrm{ha}$ on 15 or 25 DAS significantly enhanced the number of branches per plant, pods/plant, 1000-seed weight and seed yield of soybean. Combined tank-mix application of propaquizafop + imazethapyr, propaquizafop + chlorimuron ethyl and quizalofop ethyl + chlorimuron ethyl had more branches/plant, seeds/pod, 1000-seed weight and seed yield than other chemical treatments. These combinations were comparable to hand weeding in influencing yield attributes and seed yield of soybean.

\section{Introduction}

Soybean (Glycine max. L. Merrill.) grown in rainy season faces severe weed competition. It has a good suppressing ability against weeds appearing late in the season. However, the crop suffers severely due to early competitive stress of grasses, sedges and broad-leaved weeds. The weeds cause yield reductions to the extent of 20 to $77 \%$ (Tiwari and Kurchania, 1990; Kurchania et al., 2001) depending upon the nature, intensity and duration of infestation. Non-adoption of the proper weed control is the major reason for its low productivity in Himachal Pradesh. Weeds compete with crop in initial stages for limited essential resources and seriously depress the crop growth and development (Singh et al., 1984). Weeds increase cost of cultivation and deplete resource base (Buriro et al., 2003). The effective and economical weed control may not be possible through manual or mechanical means due to heavy and continuous rainfall in kharif. Hence, use of herbicides offers an alternative to manage weeds in this situation. The herbicides presently available are either pre-emergence or pre-plant incorporated and have a narrow spectrum of weed control. Further, if farmers skip application of these pre-emergence or pre-plant incorporated herbicides due to one or the other reason, require an alternative post 
emergent herbicide application for managing weeds in soybean. Therefore, there is a need of new post-emergent herbicide which must have broader spectrum of activity. Keeping these facts in view, the present investigation was carried out to evaluate propaquizafop for an effective weed control in soybean.

\section{Materials and Methods}

The field experiment with eleven treatments constituting of propaquizafop 60 and $75 \mathrm{~g} / \mathrm{ha}$ on 15 and 25 days after sowing (DAS), propaquizafop $50 \mathrm{~g} / \mathrm{ha}$ tank-mixed with imazethapyr $100 \mathrm{~g}$ and chlorimuron ethyl 4 $\mathrm{g} / \mathrm{ha}$ on $20 \mathrm{DAS}$, quizalofop ethyl $60 \mathrm{~g}+$ chlorimuron ethyl $4 \mathrm{~g} / \mathrm{ha}$ on $15 \mathrm{DAS}$, preemergence pendimethalin $1500 \mathrm{~g} / \mathrm{ha}$, hand weeding and mechanical weeding (20 and 40 DAS) and weedy check was conducted at Palampur during the rainy season of 2016.

The experiment was laid out in Randomized Block Design with three replications. The soil of the experimental site was silty clay loam in texture, acidic ( $\mathrm{pH}$ 5.6) in reaction, low in available $\mathrm{N}$ (128 kg ha-1) and medium in available $\mathrm{P}$ (13.9 kg ha-1) and $\mathrm{K}(155 \mathrm{~kg} / \mathrm{ha})$. The crop was fertilized with $20 \mathrm{~kg} \mathrm{~N}, 60 \mathrm{~kg}$ $\mathrm{P}_{2} \mathrm{O}_{5}$ and $40 \mathrm{~kg} \mathrm{~K} \mathrm{~K}_{2} \mathrm{O} / \mathrm{ha}$ through urea, single super phosphate and muriate of potash, respectively. Full dose of nitrogen, phosphorus, potassium through urea, single super phosphate and muriate of potash was applied at the time of sowing (as per the recommended package of practices).

The herbicides were applied using Knapsack sprayer fitted with flat fan nozzle at a spray volume of 600 litres of water per ha. The data on weed population were recorded at 30,60 , 90 and at harvest but described only at their maximum dry weight stage i.e. at 60 DAS. Observations on yield attributing and yield were recorded at harvest. The experimental data on weed count, yield and yield parameters were subjected to statistical analysis as per Gomez and Gomez (1984) and were tested at 5 per cent level of significance to interpret the treatment differences. Rest of the package of practices was as per the recommendations of the university.

\section{Results and Discussion}

\section{Weed count}

Major weed flora associated with the soybean crop was constituted of Echinochloa colona (22.3\%), Commelina benghalensis (19.2\%), Cyperus iria (28.2\%), Ageratum conyzoides $(10.2 \%)$ and Polygonum alatum (11.8\%). The other minor weeds viz. Panicum dichotomiflorum, Euphorbia sp and Bidens pilosa as a whole constituted $8.4 \%$ of the total weed flora.

All weed control treatments were significantly superior to weedy check in reducing the population of E. colona, C. benghalensis and C. Iria. Propaquizafop 50g + imazethapyr 100 $\mathrm{g} / \mathrm{ha}$ on 20 DAS was as effective as hand weeding twice in reducing the population of $E$. colona. The effective control of E. colona with hand weeding has also reported by Rao and Rao (2003). All weed control treatments except pre-emergence application of pendimethalin at $1500 \mathrm{~g} / \mathrm{ha}$ were significantly superior to weedy check in reducing the count of $C$. benghalensis. Hand weeding twice remaining at par with propaquizafop $50 \mathrm{~g}+$ imazethapyr $100 \mathrm{~g} / \mathrm{ha}$ on 20 DAS resulted in significantly lower population of $C$. benghalensis. Tank-mix application of propaquizafop $50 \mathrm{~g}+$ imazethapyr $100 \mathrm{~g} / \mathrm{ha}$, propaquizafop $50 \mathrm{~g}+$ chlorimuron-ethyl 4 $\mathrm{g} / \mathrm{ha}$, quizalofop-ethyl $60 \mathrm{~g}+$ chlorimuronethyl $4 \mathrm{~g} / \mathrm{ha}$ and hand weeding (20 and 40 DAS) gave better control of $C$. iria than other treatments. Panda et al., (2015) also reported effective control of $C$. iria with imazethapyr in soybean. Hand weeding (20 and 40 DAS) 
gave lower count of $A$. conyzoides followed by tank mix application of propaquizafop $50 \mathrm{~g}+$ imazethapyr at $100 \mathrm{~g} / \mathrm{ha}$ and propaquizafop $50 \mathrm{~g}+$ chlorimuron-ethyl $4 \mathrm{~g} /$ ha (Table 1 ). However, sole application of propaquizafop at different times and doses and pre-emergence application of pendimethalin could not significantly reduce the population of Ageratum. Propaquizafop at $50 \mathrm{~g} / \mathrm{ha}$ in combination with imazethapyr $100 \mathrm{~g} / \mathrm{ha}$ resulted in complete elimination of $P$. alatum. However, post emergence application of propaquizafop could not significantly reduce its count over weedy check.

\section{Yield attributes and yield}

Phytotoxicity was not observed in pre- and post-emergence herbicidal treatments (data not shown). The results are in conformity with Aggarwal et al., (2014) and Chandrakar et al., (2014). The data on effect of different treatments on yield attributes and yield of soybean have been presented in Table 2 . Number of plants per square metre was not significantly affected due to weed control treatments.

All weed control treatments increased number of branches/plant significantly over weedy check. Among all the treatments, the minimum number of pods per plant was recorded under weedy check (7.3), which was increased significantly when weed control measures were adopted. Application of propaquizafop $75 \mathrm{~g} / \mathrm{ha}$ on 15 or $25 \mathrm{DAS}$ significantly enhanced the number of branches per plant than the other propaquizafop dose in soybean. But combined tank-mix application of propaquizafop + imazethapyr had more number of branches per plant than other treatments. However, none of the herbicidal treatments surpassed hand weeding (20 and 40 DAS) which proved significantly superior over other treatments except propaquizafop $50 \mathrm{~g}+$ imazethapyr $100 \mathrm{~g} / \mathrm{ha}$, quizalofop-ethyl
$60 \mathrm{~g}+$ chlorimuron-ethyl 4 g/ha and propaquizafop $50 \mathrm{~g}+$ chlorimuron-ethyl $4 \mathrm{~g} / \mathrm{ha}$ on 20 DAS. Pendimethalin $1000 \mathrm{~g} / \mathrm{ha}$ was as similar as propaquizafop $75 \mathrm{~g} / \mathrm{ha}$ on $25 \mathrm{DAS}$.

Weed control treatments significantly affected numbers of pods/plant (Table 2). Postemergence application of propaquizafop 75 g/ha on 15 and 25 DAS significantly enhanced the number of pods/plant than other sole treatments of propaquizafop $60 \mathrm{~g} / \mathrm{ha}$. Hand weeding (20 and 40 DAS) significantly increased the number of pods per plant which was at par to tank mixtures of propaquizafop $50 \mathrm{~g}+$ imazethapyr $100 \mathrm{~g} / \mathrm{ha}$ and propaquizafop $50+$ chlorimuron-ethyl $4 \mathrm{~g} / \mathrm{ha}$ applied on 20 DAS. Weed control treatments had no significant effect on the number of seeds per pod as might be governed by genetic factor. It was evident from data (Table 2) that weed control treatments significantly influenced 1000-seed weight. All weed control treatments significantly increased 1000-seed weight over the weedy check. Application of propaquizafop $75 \mathrm{~g} / \mathrm{ha}$ on 15 and $25 \mathrm{DAS}$ significantly enhanced 1000-seed weight than the other sole treatments of propaquizafop in soybean. But, combined tank-mix application of propaquizafop $50+$ imazethapyr $100 \mathrm{~g} / \mathrm{ha}$ had more 1000-seed weight than other chemical treatments. However, none of the herbicidal treatments surpassed hand weeding (20 and 40 DAS) which proved significantly superior over other treatments except propaquizafop $50+$ imazethapyr $100 \mathrm{~g} / \mathrm{ha}$ on 20 DAS. Improvement in yield contributing characters due to these treatments may be attributed to significantly lower weed density which created favourable condition for better plant growth and development in the crop. These results are in conformity with Aggarwal et al., (2014) and Mansoori et al., (2015).

The seed yield under weedy check was 10.23 q/ha, which increased significantly when weed control measures were adopted. 
Table.1 Effect of treatments on species-wise $\left(\mathrm{No} . / \mathrm{m}^{2}\right)$ weed density at maximum population stage i.e. 60 DAS

\begin{tabular}{|c|c|c|c|c|c|c|c|}
\hline Treatment & $\begin{array}{l}\text { Dose } \\
\text { (g/ha) }\end{array}$ & $\begin{array}{l}\text { TOA } \\
\text { (DAS) }\end{array}$ & $\begin{array}{c}E . \\
\text { colona }\end{array}$ & $\begin{array}{c}C . \\
\text { benghalensis }\end{array}$ & $\begin{array}{l}\text { C. } \\
\text { iria }\end{array}$ & $\begin{array}{c}\text { A. } \\
\text { conyzoides }\end{array}$ & $\begin{array}{c}P . \\
\text { alatum }\end{array}$ \\
\hline Propaquizafop & 60 & 15 & $\begin{array}{c}6.4 \\
(40.3)\end{array}$ & $\begin{array}{c}6.0 \\
(35.4)\end{array}$ & $\begin{array}{c}10.0 \\
(100.4)\end{array}$ & $\begin{array}{c}6.1 \\
(36.3)\end{array}$ & $\begin{array}{c}6.5 \\
(41.4)\end{array}$ \\
\hline Propaquizafop & 60 & 25 & $\begin{array}{c}6.3 \\
(39.5)\end{array}$ & $\begin{array}{c}5.7 \\
(32.0)\end{array}$ & $\begin{array}{c}10.0 \\
(99.3)\end{array}$ & $\begin{array}{c}6.0 \\
(35.1)\end{array}$ & $\begin{array}{c}6.4 \\
(40.0)\end{array}$ \\
\hline Propaquizafop & 75 & 15 & $\begin{array}{c}5.9 \\
(34.7)\end{array}$ & $\begin{array}{c}5.2 \\
(26.1)\end{array}$ & $\begin{array}{c}9.9 \\
(98.5)\end{array}$ & $\begin{array}{c}5.9 \\
(34.3)\end{array}$ & $\begin{array}{c}6.3 \\
(39.1)\end{array}$ \\
\hline Propaquizafop & 75 & 25 & $\begin{array}{c}5.8 \\
(33.1)\end{array}$ & $\begin{array}{c}4.6 \\
(20.7)\end{array}$ & $\begin{array}{c}9.9 \\
(97.2)\end{array}$ & $\begin{array}{c}5.9 \\
(33.9)\end{array}$ & $\begin{array}{c}6.2 \\
(38.4)\end{array}$ \\
\hline $\begin{array}{l}\text { Propaquizafop+ } \\
\text { imazethapyr }\end{array}$ & $50+100$ & 20 & $\begin{array}{c}4.6 \\
(20.7)\end{array}$ & $\begin{array}{c}4.1 \\
(16.0)\end{array}$ & $\begin{array}{c}5.7 \\
(32.0)\end{array}$ & $\begin{array}{c}2.7 \\
(6.8)\end{array}$ & $\begin{array}{c}0.7 \\
(0.0)\end{array}$ \\
\hline $\begin{array}{l}\text { Propaquizafop+chlorimuron } \\
\text { ethyl }\end{array}$ & $50+4$ & 20 & $\begin{array}{c}5.7 \\
(32.0)\end{array}$ & $\begin{array}{c}5.2 \\
(26.1)\end{array}$ & $\begin{array}{c}6.5 \\
(42.3)\end{array}$ & $\begin{array}{c}3.0 \\
(8.3)\end{array}$ & $\begin{array}{c}3.8 \\
(14.3)\end{array}$ \\
\hline $\begin{array}{l}\text { Quizalofop ethyl + } \\
\text { chlorimuron ethyl }\end{array}$ & $60+4$ & 15 & $\begin{array}{c}5.2 \\
(26.1)\end{array}$ & $\begin{array}{c}4.4 \\
(18.6)\end{array}$ & $\begin{array}{c}6.1 \\
(37.0)\end{array}$ & $\begin{array}{c}4.1 \\
(16.0)\end{array}$ & $\begin{array}{c}4.1 \\
(16.0)\end{array}$ \\
\hline Pendimethalin & 1500 & Pre- & $\begin{array}{c}6.5 \\
(42.3)\end{array}$ & $\begin{array}{c}7.7 \\
(58.4)\end{array}$ & $\begin{array}{c}10.1 \\
(101.0)\end{array}$ & $5.226 .1)$ & $\begin{array}{c}4.6 \\
(20.7)\end{array}$ \\
\hline Hand weeding twice & - & $\begin{array}{c}20 \text { and } \\
40\end{array}$ & $\begin{array}{c}4.1 \\
(16.0)\end{array}$ & $\begin{array}{c}2.9 \\
(7.7)\end{array}$ & $\begin{array}{c}4.6 \\
(20.7)\end{array}$ & $\begin{array}{c}1.8 \\
(2.7)\end{array}$ & $\begin{array}{c}2.9 \\
(8.2)\end{array}$ \\
\hline Mechanical weeding & - & $\begin{array}{c}20 \text { and } \\
40\end{array}$ & $\begin{array}{c}7.0 \\
(48.0)\end{array}$ & $\begin{array}{c}6.1 \\
(37.0)\end{array}$ & $\begin{array}{c}7.0 \\
(48.0)\end{array}$ & $\begin{array}{c}4.6 \\
(20.7)\end{array}$ & $\begin{array}{c}3.7 \\
(13.0)\end{array}$ \\
\hline Weedy check & - & - & $\begin{array}{c}9.0 \\
(80.0)\end{array}$ & $\begin{array}{c}8.3 \\
(69.1)\end{array}$ & $\begin{array}{c}10.1 \\
(101.2)\end{array}$ & $\begin{array}{c}6.1 \\
(36.7)\end{array}$ & $\begin{array}{c}6.5 \\
(42.3)\end{array}$ \\
\hline $\mathrm{CD}(\mathrm{P}=0.05)$ & & & 1.0 & 1.2 & 1.0 & 1.2 & 1.4 \\
\hline
\end{tabular}

Data transformed to square root transformation $(\sqrt{x+0.5})$. *Value in parentheses are the means of original values. $\mathrm{TOA}=$ Time of application; pre-, pre-emergence

Table.2 Effect of treatments on yield attributes and yield of soybean

\begin{tabular}{|c|c|c|c|c|c|c|c|c|}
\hline Treatment & $\begin{array}{l}\text { Dose } \\
\text { (g/ha) }\end{array}$ & $\begin{array}{c}\text { TOA } \\
\text { (DAS) }\end{array}$ & $\begin{array}{c}\text { Plant } \\
\text { count }\left(\text { No. } / \mathrm{m}^{2}\right)\end{array}$ & $\begin{array}{c}\text { Branches/ } \\
\text { plant }\end{array}$ & $\begin{array}{l}\text { Pods/ } \\
\text { plant }\end{array}$ & $\begin{array}{l}\text { Seeds/ } \\
\text { pod }\end{array}$ & $\begin{array}{l}1000 \text { - seed } \\
\text { weight }(\mathrm{g})\end{array}$ & $\begin{array}{l}\text { Seed yield } \\
\text { (q/ha) }\end{array}$ \\
\hline Propaquizafop & 60 & 15 & 10.4 & 9.0 & 33.3 & 2.0 & 156.7 & 11.64 \\
\hline Propaquizafop & 60 & 25 & 11.1 & 9.7 & 34.3 & 2.0 & 157.0 & 13.40 \\
\hline Propaquizafop & 75 & 15 & 11.9 & 10.3 & 36.7 & 2.0 & 157.7 & 14.11 \\
\hline Propaquizafop & 75 & 25 & 11.9 & 11.0 & 37.0 & 2.3 & 158.0 & 14.81 \\
\hline $\begin{array}{l}\text { Propaquizafop + } \\
\text { imazethapyr }\end{array}$ & $\begin{array}{c}50+ \\
100\end{array}$ & 20 & 13.3 & 12.3 & 42.7 & 2.4 & 162.0 & 22.22 \\
\hline $\begin{array}{l}\text { Propaquizafop + } \\
\text { chlorimuron ethyl }\end{array}$ & $50+4$ & 20 & 12.6 & 11.7 & 39.0 & 2.3 & 160.7 & 18.34 \\
\hline $\begin{array}{l}\text { Quizalofop ethyl + } \\
\text { chlorimuron ethyl }\end{array}$ & $60+4$ & 15 & 12.6 & 12.0 & 42.3 & 2.4 & 161.0 & 20.63 \\
\hline Pendimethalin & 1500 & Pre- & 12.6 & 11.2 & 38.7 & 2.1 & 160.0 & 16.75 \\
\hline Hand weeding & - & $\begin{array}{c}20 \text { and } \\
40\end{array}$ & 13.3 & 12.7 & 43.7 & 2.5 & 162.7 & 23.63 \\
\hline $\begin{array}{l}\text { Mechanical } \\
\text { weeding }\end{array}$ & - & $\begin{array}{c}20 \text { and } \\
40\end{array}$ & 11.9 & 10.7 & 37.0 & 2.3 & 159.3 & 15.70 \\
\hline Weedy check & - & - & 10.4 & 7.3 & 30.3 & 2.0 & 155.9 & 10.23 \\
\hline $\mathrm{CD}(\mathrm{P}=0.05)$ & & & NS & 1.8 & 4.5 & NS & 1.2 & 4.5 \\
\hline
\end{tabular}

TOA: Time of application; DAS: Days after sowing 
Post-emergence application of propaquizafop at $75 \mathrm{~g} / \mathrm{ha}$ on 15 and 25 DAS significantly increased the seed yield than the lower dose of propaquizafop $(60 \mathrm{~g} / \mathrm{ha})$ in soybean.

Combined tank-mix application of propaquizafop + imazethapyr had more seed yield than other chemical treatments. Propaquizafop 50g + imazethapyr $100 \mathrm{~g} / \mathrm{ha}$ on 20 DAS and quizalofop-ethyl $60 \mathrm{~g}+$ chlorimuron-ethyl $4 \mathrm{~g} / \mathrm{ha}$ applied on 15 DAS were comparable to hand weeding in influencing seed yield of soybean.

The higher seed yield in these treatments could be attributed to improved yield contributing characters.

This improvement was due to lower weed competition, which shifted the balance in favour of crop in utilization of nutrients, moisture, light and space.

The present investigation conclusively revealed the superiority of propaquizafop 75 $\mathrm{g} / \mathrm{ha}$ on 15-25 DAS for controlling grassy weeds in soybean. However, for mixed weed flora management and higher yield attributes and yield, tank mixed propaquizafop $50 \mathrm{~g}+$ imazethapyr $100 \mathrm{~g} / \mathrm{ha}$ on $20 \mathrm{DAS}$ or propaquizafop $50 \mathrm{~g}+$ chlorimuron-ethyl $4 \mathrm{~g} / \mathrm{ha}$ on 20 DAS are recommended as an alternative/rotational use to quizalofop-ethyl $60 \mathrm{~g}+$ chlorimuron-ethyl $4 \mathrm{~g} / \mathrm{ha}$ applied on 15 DAS.

\section{References}

Aggarwal N, Singh G, Ram H and Khanna V. 2014. Effect of post-emergence application of imazethapyr on symbiotic activities, growth and yield of black gram (Vigna mungo) cultivars and its efficacy against weeds. Indian Journal of Agronomy 59: 421-426

Buriro UA, Oad FC, Agha SK and Solangi GS. 2003. Post-emergence weed control in wheat. Journal of Applied Sciences 3: 424-427

Chandrakar DK, Nagre SK, Chandrakar K, Singh AP and Nair SK. 2014. Chemical weed management in black gram. In: Extended Summary of Biennial Conference of Indian Society of Weed Science, DSWR, Jabalpur (M.P.) p 242

Gomez KA and Gomez AA. 1984. Statistical procedures for agricultural research. John Willey and Sons, New York, USA.

Kurchania SP, Rathi GS, Bhalla CS and Mathew R. 2001. Bioefficacy of post-emergent herbicides for weed control in soybean [Glycine max (L.) Merr.]. Indian Journal of Weed Science 33 (1/2): 34-37.

Mansoori N, Bhadauria N and Rajput RL. 2015. Effect of weed control practices on weeds and yield of black gram (Vigna mungo). Legume Research 38: 855-857

Panda S, Lal S, Kewat ML, Sharma JK and Saini MK. 2015. Weed control in soybean with propaquizafop alone and in mixture with imazethapyr. Indian Journal of Weed Science 47: 31-33

Rao AS and Rao RSN. 2003. Bioefficicacy of clodinafop propargyl on Echinochloa sp. in black gram. Indian Journal of Weed Science 35: 251-252

Singh KK and Kharwara PC. 1984. Comparative efficiency of some herbicides in controlling weeds in pure stand of soybean. In: Proceeding of Annual Weed Science Conference. Indian Society of Weed Science: 35-36.

Tiwari, J.P., and Kurchania SP. 1990. Survey and management of weeds in soybean (Glycine max) ecosystem in Madhya Pradesh. Indian Journal of Agricultural Sciences 6: 672-676.

\section{How to cite this article:}

Sachin Kumar, M.C. Rana and Rana, S.S. 2018. Effect of Propaquizafop on Weed Count, Yield Attributes and Yield of Soybean under Mid Hill Conditions of Himachal Pradesh, India. Int.J.Curr.Microbiol.App.Sci. 7(04): 771-775. doi: https://doi.org/10.20546/ijcmas.2018.704.086 